\title{
PERAN REGULATOR TERHADAP STANDAR AKUNTANSI KEUANGAN (SAK) SAAT PANDEMI COVID-19 di INDONESIA
}

\author{
John Fery Sonoto* \\ Universitas Hein Namotemo \\ *e-mail: johnsonotounhena@yahoo.com
}

\author{
DiPublikasi: 01/07/2021 \\ https://doi.org/10.22225/kr.13.1.2021.50-58
}

\begin{abstract}
A business entity should consider going concern in preparing its financial statements if there are events that are significant after the reporting period that could threaten the going concern of the business in the future. Entities should use their judgment on whether the Covid-19 pandemic may affect the entity's business continuity taking into account all relevant facts and information. The Financial Services Authority (OJK) together with the Indonesian Institute of Accountants (IAI) as the authorized institution to provide a positive signal for the continuity of the entity's business, through adjustments to PSAK 68 concerning the measurement of fair value of securities and PSAK 71 concerning calculation of reserves. This article proves that the government, in this case the OJK and IAI, has the authority to choose the accounting standards to apply.
\end{abstract}

Keywords: Reporting Period, Adjustment of PSAK 68 and PSAK 71, Fair Value, loss view

\begin{abstract}
Abstrak
Entitas bisnis harus mempertimbangkan kelangsungan usaha dalam penyusunan laporan keuangan jika terdapat peristiwa setelah periode pelaporan yang sangat signifikan sehingga dapat mengancam kelangsungan usaha di masa depan. Entitas harus menggunakan pertimbangannya apakah pandemi Covid-19 dapat memengaruhi kelangsungan usaha entitas dengan mempertimbangkan semua fakta dan informasi yang relevan. Otoritas Jasa Keuangan (OJK) bersama Ikatan Akuntan Indonesia (IAI) sebagai lembaga berwenang memberikan signal positif bagi kelangsungan usaha entitas, melalui penyesuaian PSAK 68 mengenai pengukuran nilai wajar surat berharga dan PSAK 71 mengenai penghitungan pencadangan. Artikel ini membuktikan bahwa pemerintah dalam hal ini OJK dan IAI berwenang memilih standar akuntansi yang akan diberlakukan.
\end{abstract}

Kata Kunci : Periode Pelaporan, Penyesuaian PSAK 68 dan PSAK 71, Fair Value, pencandangan kerugian

\section{PENDAHULUAN}

Pandemi Corona Virus Disease 2019 (Covid19) telah mengakibatkan siklus ekonomi dunia mengalami guncangan hebat. Krisis moneter pada Tahun 1997 dan melambatnya ekonomi Amerika tahun 2007 menjadi pembanding terhadap iklim ekonomi Indonesia masa pandemi Covid19. Covid19 di Indonesi pertama kali pada 2 Maret 2020, terinfeksi kepada 2 (dua) warga negara Indonesia yang berdomisili di Depok oleh warga Jepang. (Indonesia.go.id).

Sejak temuan kasus Covid-19 pertama di Indonesia itu disampaikan langsung oleh Presiden Joko Widodo, Senin 2/3/2020, di Jakarta (Indonesia.go.id) hingga April 2020, sektor-sektor ekonomi Indonesia ikut terdampak, diantaranya:

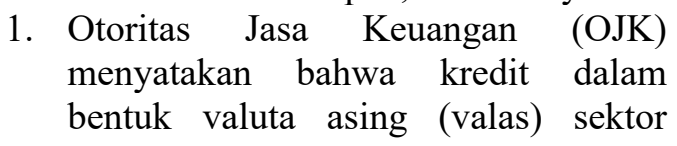

swasta mengalami peningkatan. Data OJK menunjukkan per Maret 2020 pertumbuhan kredit valas meningkat 16,54 persen secara year on year (yoy). Sejalan dengan itu, pada Maret 2020, OJK mencatat terjadi pelemahan rupiah hingga di kisaran Rp16.367 per dolar AS. Pada Maret 2020 pertumbuhan kredit berdenominasi rupiah mengalami tren menurun hanya pada kisaran 6,32 persen yoy. Namun secara total kredit terjadi tren naik mulai Februari ke Maret 2020 pertumbuhannya 7,95 persen yoy. (tirto.id)

2. Indeks PMI Manufaktur (Purchasing Managers' Index) adalah indikator ekonomi yang mencerminkan 
keyakinan para manajer bisnis di sektor manufaktur, sehingga berdampak di pasar saham dan pasar forex. Kinerja manufaktur berdasarkan data Bank Indonesia (BI) pada kuartal I-2020 periode Februari tercatat 45,64 $\%$ sedangkan kuartal II-2020 periode Maret 2020 berada pada kisaran 45,3\%. Memperhatikan pertumbuhannya menujukkan penurunan bahka berada pada fase kontraksi. (contan.co.id dan katadata.co.id)

3. Sebanyak 1.139 hotel telah tutup dan 1.174 hotel tutup dengan mengenakan cuti atau PHK terhadap karyawannya. (smol.id)

4. Terdapat kurang lebih 1,2 juta karyawan yang mengalami Pemutusan Hubungan Kerja (PHK) dan dirumahkan.

5. Sebanyak 18.300 penerbangan di 15 bandara milik PT Angkasa Pura I (Persero) dibatalkan dengan periode pembatalan terjadi mulai Januari hingga Maret 2020. (tempo.co),

6. Indeks harga konsumen pada triwulan I-2020 per Januari 104,33, Februari 104,62, Maret 104,72 sementara Inflasi per januari 0,39 , februari 0,28 dan Maret 0,10 (bps.go.id.)

Direktur Pelaksana__Dana Moneter Internasional (International Monetary Fund/ IMF) Kristalina Georgieva dan Ketua Komite Moneter dan Keuangan Internasional (International Monetary and Financial Committee/IMFC) Lesetja Kganyago menyatakan bahwa, pandemi virus corona (Covid-19) merupakan situasi yang belum pernah terjadi sebelumnya di mana pandemi kesehatan global telah berubah menjadi krisis ekonomi dan keuangan. (republika.co.id) Demi penyelamatan Negara Kesatuan Republik Indonesia atas gejolak sosial, ekonomi, pertahanan dan keamanan, Negara hadir memberikan kepastian stabilitas kepada seluruh warga bangsa sehingga Presiden Joko Widodo mengumumkan sembilan kebijkan nasional, yakni:

Pertama, Gubernur dan wali kota memangkas rencana belanja yang bukan belanja prioritas dalam Anggaran Pendapatan dan Belanja Negara (APBN) dan Anggaran Pendapatan dan Belanja Daerah
(APBD).

Kedua, Pemerintah pusat dan pemerintah daerah untuk mengalokasikan ulang anggarannya untuk mempercepat pengentasan dampak corona, baik dari sisi kesehatan dan ekonomi. Langkah tersebut sesuai dengan Instruksi Presiden (Inpres) Nomor 4 Tahun 2020 tentang Tentang Refocussing Kegiatan, Realokasi Anggaran serta Pengadaan Barang dan Jasa dalam rangka Percepatan Penanganan Corona Virus Disease 2019.

Ketiga, Pemerintah pusat serta pemerintah daerah menjamin ketersediaan bahan pokok, diikuti dengan memastikan terjaganya daya beli masyarakat, terutama masyarakat lapisan bawah.

Keempat, Program Padat Karya Tunai diperbanyak dan dilipatgandakan, dengan catatan harus diikuti dengan kepatuhan terhadap protokol pencegahan virus corona, yaitu menjaga jarak aman satu sama lain. Khususnya tentang program Padat Karya Tunai di beberapa kementerian, seperti Kementerian Pekerjaan Umum dan Perumahan Rakyat (PUPR), Kementerian Perhubungan, Kementerian Pertanian, dan Kementerian Kelautan dan Perikanan.

Kelima, Pemerintah memberikan tambahan sebesar Rp 50.000 pada pemegang kartu sembako murah selama enam bulan. Dengan demikian, peserta kartu sembako akan menerima Rp 200.000 per keluarga per bulan. Untuk menjalankan alokasi tambahan kartu sembako ini, pemerintah menganggarkan biaya $\mathrm{Rp} \mathrm{4,56} \mathrm{triliun.}$

Keenam, mempercepat impelemntasi kartu pra-kerja guna mengantisipasi pekerja yang terkena PHK, pekerja kehilangan penghasilan, dan penugusaha mikro yang kehilangan pasar dan omzetnya. Masyarakat yang terdampak diharapkan tersebut dapat meningkatkan kompetensi dan kulitasnya melalui pelatihan kartu pra kerja. Tahun ini, pemerintah telah mengalokasikan Rp 10 triliun untuk kartu pra kerja.

Ketujuh, pemerintah juga membayarkan pajak penghasilan $(\mathrm{PPh})$ Pasal 21 yang selama ini dibayar oleh wajib pajak (WP) karyawan di industri 
pengolahan. Alokasi anggaran yang disediakan mencapai Rp 8,6 triliun.

Kedelapan, Otoritas Jasa Keuangan (OJK) memberikan relaksasi kredit di bawah Rp 10 miliar untuk Usaha Mikro Kecil dan Menengah (UMKM). Relaksasi tersebut berupa penurunuan bunga dan penundaan cicilan selama setahun, baik dari perbankan dan industri keuangan non bank. Selain itu, penangguhan cicilan selama setahun juga berlaku bagi ojek, supir taksi dan nelayan yang memiliki cicilan kendaraan. Pihak perbankan dan keuangan non bank untuk tidak mengejar para debitur.

Kesembilan, masyarakat berpenghasilan rendah yang melakukan kredit kepemilikan rumah (KPR) bersubsidi, akan diberikan stimulus. Pemerintah memberikan subsidi bunga hingga masa angsuran 10 tahun. Jika bunga di atas 5 persen, maka selisih bunga dibayar pemerintah. Selain itu, ada juga bantuan pemberian subsidi uang muka bagi kredit rumah bersubsidi, dengan alokasi anggaran yang disiapkan mencapai $\mathrm{Rp}$ 1,5 triliun. (Kompas.com)

Poin kedelapan dari kesembilan kebijakan nasional diatas, menunjukkan bahwa sektor jasa keuangan ikut terpengaruh sehingga menimbulkan

\section{HASIL DAN PEMBAHASAN Industri Perbank di Indonesia}

Salah satu yang terdampak langsung Covid-19 yaitu industri perbankan. Perbankan adalah salah satu industri yang mampu mempengaruhi secara signifikan kondisi perekonomian suatu negara. Bank berfungsi sebagai badan usaha untuk menghimpun dana dari masyarakat dalam bentuk simpanan dan menyalurkannya kepada masyarakat dalam bentuk kredit atau bentuk lainnya dalam rangka meningkatkan taraf hidup masyarakat. OJK ketidakpastian ekonomi global dan domestik secara signifikan. Konsekuensi ekonomi yang tidak stabil sangat mempangaruhi standar akuntansi dengan demikian produktivitas Emiten, Perusahaan Publik, dan Auditor ikut terganggu (Wolk, Harry I., James L. Dodd, n.d.). Standar yang dipublikasikan oleh otoritas akuntansi dalam hal ini di Indonesia adalah OJK, pada umumnya memberikan alternatif pilhan level metode akuntansi, yaitu 1) Otoritas akuntansi berwenang memilih standar akuntansi yang akan diberlakukan, dan 2) Manajemen organisasi berwenang memilih metode akuntansi yang akan digunakan dalam organisasinya. (Baridwan, 2000)

Masa pandemi Covid19 OJK bersama Dewan Standar Akuntansi Keuangan - Ikatan Akuntansi Indonesia (DSAK - IAI) melaksanakan fungsinya sebagai regulator, nampaknya tidak memberikan pilihan atas ke-2 (kedua) level metode akuntansi seperti yang di bahas oleh Baridwan, 2000. Namun OJK berwenang memilih standar akuntansi yang akan diberlakukan.

Oleh karenanya penulis tertarik membahasnya melalui tulisan ini, sehingga penulis memberikan topik makalah ini yaitu "PERAN REGULATOR TERHADAP STANDAR AKUNTANSI KEUANGAN (SAK) SAAT PANDEMI COVID19 di INDONESIA.

mengakategorikan dalam kegiatannya, bank terbagi atas 4 (empat) kategori, yakni Bank Umum, Bank Swasta Nasional, Bank Pembangunan Daerah dan Kantor Cabang yang Berkedudukan di Luar Negeri.

Menarik bagi penulis untuk menunjukkan data statistik OJK tentang pertumbuhan bank umum dan bank perkreditan per desember 2019, Januari 2020 dan Februari 2020. Pada tabel 2 (dua) dapat dilihat pertumbuhan tersebut.

\section{Tabel 1.}

Pertumbuhan Bank Umum dan Bank Perkreditan di Indonesia

\begin{tabular}{|c|c|c|c|}
\hline \multirow{2}{*}{ Keterangan } & $\begin{array}{c}\text { Tahun } \\
\mathbf{2 0 1 9}\end{array}$ & \multicolumn{2}{|c|}{ Tahun 2020 } \\
\cline { 2 - 4 } & $\begin{array}{c}\text { Desemb } \\
\text { er }\end{array}$ & $\begin{array}{c}\text { Janu } \\
\text { ari }\end{array}$ & $\begin{array}{c}\text { Febru } \\
\text { ari }\end{array}$ \\
\hline Jumlah Bank & \multicolumn{3}{|c|}{} \\
\hline Bank Umum & 110 & 110 & 110 \\
\hline Bank Perkreditan & 1.545 & 1.542 & 1.542 \\
\hline
\end{tabular}




\begin{tabular}{|c|c|c|c|}
\hline Rakyat & & & \\
\hline \multicolumn{4}{|l|}{ Jumlah Kantor } \\
\hline Bank Umum & 31.127 & $\begin{array}{l}31.12 \\
5\end{array}$ & 31.087 \\
\hline $\begin{array}{l}\text { Bank Perkreditan } \\
\text { Rakyat }\end{array}$ & 5.939 & 5.964 & 5.930 \\
\hline
\end{tabular}

Data Olahan: Sumber ojk.go.id

Data diatas menunjukkan terjadi penurunan jumlah Bank Perkreditan Rakyat pada tahun 2020 sebanyak 3 bank. Sementara Bank Umum tetap pada angka 110. Namun pada keterangan tentang jumlah kantor diseluruh Indonesia, kedua kategori bank tersebut mengalami penurunan. Bank Umum berkurang 2 kantor dibanding bulan sebelumnya dan kembali berkurang drastis sebanyak 38 kantor per Februari 2020. Sementara Bank Perkreditan Rakyat berkurang 25 kantor dari bulan sebelumnya dan kembali berkurang drastis sebanyak 34 kantor per Februari 2020. Penulis berpendapat bahwa terjadi penutupan kantor Bank Umum di beberapa daerah di Indonesia. Sementara untuk Bank Perkreditan Rakyat mengalami penutupan induk banknya diikuti dengan penutupan kantornya di beberapa daerah di Indonesia. Hal-hal seperti ini menjadi perhatian serius karena cukup mengganggu produktivitas usaha serta taraf kejesahteraan masyarakat Indonesia.

\section{Kegiatan Usaha Perbankan}

Bank Indonesia melalui Peraturan Nomor 14/ 15 /PBI/2012 Tentang Penilaian Kualitas Aset Bank Umum pada Bab I Ketentuan Umum Pasal 1 mendefiniskan beberapa hal penting termasuk kredit dan cadangan kerugian penurunan nilai, yaitu:

Nomor 5. Kredit adalah penyediaan uang atau tagihan yang dapat dipersamakan dengan itu, berdasarkan persetujuan atau kesepakatan pinjam meminjam antara Bank dengan pihak lain yang mewajibkan pihak peminjam untuk melunasi utangnya setelah jangka waktu tertentu dengan pemberian bunga, termasuk:

a. cerukan (overdraft), yaitu saldo negatif pada rekening giro nasabah yang tidak dapat dibayar lunas pada akhir hari;

b. pengambilalihan tagihan dalam rangka kegiatan anjak piutang; dan

c. pengambilalihan atau pembelian kredit dari pihak lain.
Nomor 20. Cadangan Kerugian Penurunan Nilai yang untuk selanjutnya disebut CKPN, adalah penyisihan yang dibentuk apabila nilai tercatat aset keuangan setelah penurunan nilai kurang dari nilai tercatat awal.

Hasil penelitian membuktikan bahwa pembentukan beban CKPN berpengaruh terhadap pendapatan dan kinerja keuangan. Hal ini mengindikasikan bahwa Bank Umum Syariah wajib untuk membentuk beban CKPN untuk meminimalisir risiko dari kemungkinan terjadinya impairment. (Suhartini dan Anwar, 2016)

Penelitian tentang Pengaruh Risiko Usaha Dan Good Corporate Governance Terhadap Skor Kesehatan Bank Pada Bank Umum Swasta Nasional Devisa, hasilnya menunjukkan bahwa variabel NPL, CKPN atas Kredit, IRR, PDN, LDR, IPR, BOPO, FBIR dan GCG secara bersama-sama memiliki pengaruh yang signifikan terhadap skor kesehatan bank. Dengan kata lain risiko kredit, risiko pasar, risiko likuditas, risiko operasional dan GCG memiliki pengaruh yang signifikan terhadap skor kesehatan bank sebesar 26,9 persen (Damayanti, D D dan Chaniago, Herizon, 2014)

\section{Standar Akuntansi Keuangan}

Standar Akuntansi Keuangan (SAK) adalah Pernyataan Standar Akuntansi Keuangan (PSAK) dan Interpretasi Standar Akuntansi Keuangan (ISAK) yang diterbitkan oleh Dewan Standar Ikatan Akuntan Indonesia (DSAK IAI) dan Dewan Standar Syariah Ikatan Akuntan Indonesia (DSAS IAI) serta peraturan regulator pasar modal untuk entitas yang berada di bawah pengawasannya.

Efektif 1 Januari 2015 yang berlaku di Indonesia secara garis besar akan konvergen dengan International Financial Reporting Standards (IFRS) yang berlaku efektif 1 Januari 2014. DSAK IAI telah berhasil meminimalkan perbedaan antara kedua standar, dari tiga tahun di 1 januari 2012 menjadi satu tahun di 1 Januari 2015. Ini merupakan suatu bentuk komitmen Indonesia melalui DSAK IAI dalam memainkan perannya 
selaku satu-satunya anggota G20 di kawasan Asia Tenggara. (iaiglobal.or.id)

SAK yang efektif per 1 Januari 2020 sebanyak 43 PSAK termasuk di dalamnya adalah PSAK 8 tentang Peristiwa Setelah Periode Pelaporan, PSAK 68 tentang Pengukuran Nilai Wajar dan 71 tentang Instrumen Keuangan.

\section{PSAK 8: Peristiwa Setelah Periode Pelaporan}

DSAK dan IAI menyampaikan kepada OJK bahwa Covid-19 akan memberikan dampak signifikan terhadap Peristiwa Setelah Periode Pelaporan (PSPP). Berikut adalah rilis IAI tentang PSAK 8:

PSAK 8 paragraf 03 mendefinisikan peristiwa penyesuai setelah periode pelaporan (adjusting events) sebagai peristiwa yang memberikan bukti atas adanya kondisi pada akhir periode pelaporan. Sedangkan peristiwa nonpenyesuai setelah periode pelaporan (non-adjusting events) mengindikasikan kondisi yang timbul setelah periode pelaporan.

Memperhatikan fakta-fakta berdasarkan lini masa (timeline) yang telah terjadi, DSAK IAI memandang bahwa penyebaran Covid-19 di Indonesia bukanlah peristiwa penyesuai yang memengaruhi penyajian jumlah yang diakui di laporan keuangan 2019. Entitas harus memastikan bahwa pengukuran aset dan liabilitas mencerminkan kondisi yang ada pada tanggal pelaporan keuangan.

Namun demikian, PSAK 8 paragraf 14 juga meminta entitas mempertimbangkan asumsi kelangsungan usaha dalam penyusunan laporan keuangan jika entitas meyakini bahwa terdapat peristiwa setelah periode pelaporan yang sangat signifikan sehingga dapat mengancam kelangsungan usaha di masa depan. Entitas harus menggunakan pertimbangannya apakah pandemi Covid-19 dapat memengaruhi kelangsungan usaha entitas dengan mempertimbangkan semua fakta dan informasi yang relevan, termasuk program-program relaksasi yang diberikan pemerintah. (iaiglobal.or.id)

Gambaran penjelasan diatas menjadi panduan bagi pemangku kepentingan terhadap pengukuran dan pengungkapan istrumen laporan keuangan dalam rangka mempertahankan kualitas reliabilitas dan komparabilitas laporan keuangan entititas
Memperhatikan panduan DSAK dan IAI, OJK sebagai regulator akuntansi di Indonesia pada 15 April 2020 mengeluarkan panduan penyusunan laporan keuangan terutama dalam menerapkan ketentuan Pernyataan Standar Akuntansi Keuangan (PSAK) 71 mengenai penghitungan pencadangan dan PSAK 68 mengenai pengukuran nilai wajar surat berharga.

\section{PSAK 68: Pengukuran Nilai Wajar}

Tahun 2020 menjadi momentum bagi Akuntan Indonesia untuk mendapat pengakuan secara maksimal dari komunitas internasional. Salah satu kekuatan akuntan Indonesia karena telah mengadopsi Internasional Financial Reporting Standards-(IFRS) merupakan standar akuntansi internasional, yang interpretasi dan kerangka kerja dalam penyusunan dan penyajian laporan keuangan diadopsi oleh IASB (International Acounting Standar Board). (Wolk et al, 2008)

Financial Accointing StandardsB oard (FASB) mengeluarkanS FASN No. 157 tentang "Pengukuran-Fair Value," yang bertujuan mendefinisikan nilai wajar, membangun suatu rerangka untuk mengukur nilai wajar, dan memperluas

pengungkapan tentang pengukuran nilai wajar (FASB, 2006).

SFAS No.157, Fair value measuremenents digunakan untuk aset dan kewajiban tertentu. Pengukuran ini mengasumsikan bahwa aset dan kewajiban dipertukarkan pada suatu transaksi wajar antara pelaku pasar ketika menjual aset atau menyelesaikan kewajiban pada tanggal pengukuran. Teknik penilaian yang digunakankan dengan 3 (tiga) pendekatan, sebagai berikut:

\section{Pendekatan Pasar}

Pendekatan ini menggunakan harga dan informasi relevan lainnya yang dihasilkan oleh transaksi pasar yang melibatkan aset dan kewajiaban yang sejenis atau dapat dibandingkan.

\section{Pendekatan Pendapatan}

Pendekatan ini menggunakan teknik penilaian dengan mengkonversi nilai masa depan ke dalam nilai sekarang. Alat analisis yang dapat digunakan adalah teknik present value; option pricing models seperti formula Black-scholes-Merton, model binomial, dan metode multiperiod excess earnings untuk mengukur nilai wajar aset tak berwujud.

3. Pendekatan Biaya

Pendekatan ini berdasarkan pada jumlah yang 
sekarang dapat diperoleh untuk mengganti kapasitas aset (atau seringkali mengarah pada current replacement cost).

Untuk meningkatkan komparabilitas dan konsistensi dalam pengukuran ini, SFAS No. 157 menyediakan hirarki nilai wajar (Wolk, Harry I., James L. Dodd, n.d.) Hirarki nilai wajar memprioritaskan pada input untuk mengukur nilai wajar ke dalam tiga tingkatan. Tiga tingkatan dalam hirarki pengukuran nilai wajar adalah:

\section{Level 1}

Tingkatan ini merupakan harga kuotasi (tidak disesuaikan) untuk aset dan kewajiban sejenis yang dilaporkan entitas yang memiliki kemampuan mengakses pasar aktif pada tanggal pengukuran (FASB, 2006). Tingkat ini mengidentifikasi prioritas tertinggi untuk input yang digunakan dalam pengukuran nilai wajar. Kualitas input sangat optimal, yaitu inputnya observable atau berdasarkan pada data pasar yang diperoleh dari sumber independen dari entitas pelaporan. Input juga diperoleh dari pasar aktif ketika hargak uotasis iapd ant ersediau ntuk digunakan (Campbell et al., 2008).

\section{Level 2}

Input pada tingkat ini merupakan kuotasi harga lainnya yang termasuk dalam level 1 yang dapat diobservasi untuk aset dan kewajiban, baik langsung maupun tidak langsung. Jika aset atau kewajiban berada pada suatu perjanjian khusus, input pada level ini harus dapat diobservasi untuk aset dan kewajiban yang penuh secara substansinya. Pada level ini mencakup:

a.Harga kuotasi untuk aset dan kewajiban sejenis dalam pasar alkif;

b. Harga kuotasi untuk aset dan kewajiban sejenis dalam pasar yang tidak aktif dapat dikatakan bahwa hanya terdapat beberapa transaksi aset dan kewajiban. Jika harga tidak diperbaharui, atau harga beragam substansial sepanjang waktu atau di antara pelaku pasar, atau dalam kondisi sedikit informasi yang dipublikasi;

c.Input selain harga kuotasi dapat di observasi untuk aset dan kewajiban;

d. Input diturunkan dari data pasar yang dapat diobservasi dengan hubungan (FASB, 2006).

\section{Level 3}

Pada level ini, input tidak dapat diobservasi untuk aset dan kewajiban. Input yang tidak dapat diobservasi dapat dikembangkan dari informasi terbaik yang tersedia dalam suatu kondisi, dan mungkin mencakup data entitas pelalporan itu sendiri (FASB, 2006).

OJK memberikan panduannya bagi industri perbankan dalam menerapkan PSAK 68 terhadap surat berharga karena tingginya volatilitas dan penurunan signifikan volume transaksi di bursa efek yang mempengaruhi pertimbangan bank dalam menentukan nilai wajar surat berharga.

Panduan kepada bank yang diberikan oleh OJK:

a.Menunda penilaian yang mengacu pada harga pasar (mark to market) untuk SUN dan suratsurat berharga lain yang diterbitkan Pemerintah termasuk surat berharga Bank Indonesia selama enam bulan. Selama masa penundaan, perbankan dapat menggunakan harga kuotasian tanggal 31 Maret 2020 untuk penilaian surat-surat berharga tersebut,

b. Menuda penilaian yang mengacu pada harga pasar (mark to market) untuk surat-surat berharga lain selama enam bulan sepanjang meyakini kinerja penerbit surat-surat berharga tersebut dinilai baik sesuai kriteria yang ditetapkan. Selama masa penundaan, perbankan dapat menggunakan harga kuotasian tanggal 31 Maret 2020 untuk penilaian surat-surat berharga tersebut. Apabil dianggap kinerja penerbit surat berharga itu tidak atau kurang baik, maka bank dapat melakukan penilaian berdasarkan model sendiri dengan menggunakan berbagai asumsi, antara lain suku bunga, credit spread, risiko kredit penerbit dan sebagainya.

c.Melakukan pengungkapan yang menjelaskan perbedaan perlakukan akuntansi yang mengacu pada panduan OJK dengan standar akuntansi sebagaimana dipersyaratkan PSAK 68. (iaiglobar.or.id)

Akuntansi nilai wajar dianggap telah berkontribusi dapat membantu meningkatkan solvabilitas perbankan saat krisis keuangan 2008. (Laux, 2010) Oleh karena itu Entitas untuk memperhatikan kondisi pasar, karena kunci utama pengukuran nilai wajar adalah kondisi pasar aktif dan tidak aktif. Dalam kondisi pasar aktif, informasi yang dihasilkan dapat memenuhi kualitas relevan, reliabel, dapat dibandingkan dan konsistensi.

Komparabilitas terganggu karena kemungkinan penggunaan teknik penilaian estimasi input yang berbeda namun tetap dapat memenuhi 
kualitas konsistensi dengan adanya pengungkapan. Pengukuran ini juga dapat menyebabkan nilai aset menurun dalam kondisi pasar tidak aktif sehingga perlu pertimbangan cost and benefit serta materialitas dalam pertimbangan pengambilan keputusan (Sonoto, 2010). Relevansi dan keandalan, tampaknya intuitif dan masuk akal, pada kenyataannya tidak dapat didefinisikan secara independen karena dapat berubah sewaktu-waktu. Kemungkinan besar para sejarawan masa depan dapat berefleksi pada titik tertinggi idealisme nilai wajar sebagai sebuah episode yang menarik di sebagian besar pengembangan pelaporan keuangan yang pragmatis. (Power, Michael. 2010)

\section{PSAK 71: INSTRUMEN KEUANGAN}

IAI memberikan klarifikasi dan panduan dalam mempertimbangkan apakah pandemi Covid19 dapat memengaruhi penghitungan kerugian kredit ekspektasian (KKE) atau expected credit loss (ECL) pada tanggal penerapan awal PSAK 71 pada 1 Januari 2020.

PSAK 71 paragraf 5.5 .17 poin (c) mensyaratkan entitas mengukur KKE dengan cara yang mencerminkan informasi yang wajar dan terdukung (reasonable and supportable information) yang tersedia tanpa biaya atau upaya berlebihan (without undue cost or effort) pada tanggal pelaporan mengenai peristiwa masa lalu, kondisi kini dan perkiraan kondisi ekonomi masa depan.

Mempertimbangkan fakta bahwa pengetahuan dan informasi mengenai pandemi Covid-19 di Indonesia tidak tersedia pada tanggal 31 Desember 2019, maka entitas tidak dapat menggunakan informasi ini dalam mengukur KKE, termasuk memasukkan informasi tersebut ke dalam skenario pemodelan sesuai estimasi probabilitas tertimbang pada tanggal penerapan awal PSAK 71 (yaitu 1 Januari 2020).

OJK meminta kepada kepada perbankan, untuk:

a.Mematuhi dan melaksanakan POJK Nomor 11/POJK.03/2020 dan secara produktif mengidentifikasi debitur-debitur yang selama ini berkinerja baik namun menurun kinerjanya karena terdampak Covid- 19.

b. Menerapkan skema restrukturisasi mengacu pada hasil asesmen yang akurat disesuaikan profil debitur dengan jangka waktu selama-lamanya satu tahun dan hanya diberikan pada debitur-debitur yang benar-benar terdampak Covid -19.

c.Menggolongkan debitur-debitur yang mendapatkan skema restrukturisasi dalam stage 1 dan tidak diperlukan tambahan Cadangan Kerugian Penurunan Nilai (CKPN)

d. Melakukan identifikasi dan monitoring secara berkelanjutan serta berjagajaga untuk tetap melakukan pembentukan CKPN apabila debitur-debitur yang telah mendapatkan fasilitas restrukturisasi tersebut berkinerja baik pada awalnya, diperkirakan menurun karena terdampak Covid -19 dan tidak dapat pulih pascarestrukturisasi atau dampak Covid berakhir (iaiglobal.or.id)

IAI menyatakan bahwa penghitungan Kerugian Kredit Ekspektasian (KKE) pada tahun 2020, terutama dikaitkan dengan beberapa kebijakan relaksasi yang dikeluarkan oleh otoritas/pemerintah.

PSAK 71 menjabarkan kerangka kerja dalam penentuan jumlah KKE yang harus diakui. Dengan pendekatan yang umumnya digunakan, pada setiap tanggal pelaporan keuangan, IAI memberikan pedoman kepada entitas cara mengukur:

a.penyisihan KKE 12 bulan (yang dalam praktiknya sering disebut sebagai berada dalam stage 1) untuk suatu instrumen keuangan, yakni risiko kerugian selama 12 bulan ke depan jika risiko kredit instrumen keuangan tidak meningkat secara signifikan sejak pengakuan awal [PSAK 71 paragraf 5.5.5]; atau

b. penyisihan KKE sepanjang umur (lifetime), yakni risiko kerugian sepanjang sisa umur ekspektasian instrumen keuangan, jika risiko kredit instrumen keuangan tersebut meningkat secara signifikan sejak pengakuan awal [PSAK 71 paragraf 5.5.3].

Dengan demikian, PSAK 71 mensyaratkan bahwa KKE sepanjang umur diakui jika terdapat Peningkatan Signifikan Dalam Risiko Kredit (PSRK) atau significant increase in credit risk (SICR) pada suatu instrumen keuangan. Penilaian atas PSRK mensyaratkan entitas untuk menilai perubahan risiko gagal bayar (risk of default) yang timbul selama umur ekspektasian dari suatu instrumen keuangan [PSAK 71 paragraf 5.5.9]. 
Dalam menilai apakah telah terjadi PSRK maupun dalam mengukur KKE, entitas mempertimbangkan seluruh informasi yang wajar dan terdukung termasuk informasi masa depan [PSAK 71 paragraf 5.5.9]. Informasi yang wajar dan terdukung merupakan informasi yang secara andal tersedia pada tanggal pelaporan keuangan yang diperoleh tanpa membutuhkan biaya atau upaya yang berlebihan, termasuk informasi mengenai peristiwa masa lalu, kondisi saat ini dan perkiraan kondisi ekonomi masa depan [PSAK 71 paragraf PP5.5.49], dan pertimbangan yang dilakukan dalam mengukur KKE [PSAK 71 paragraf PP5.5.50].

Namun demikian, PSAK 71 tidak mengatur batas yang tegas ataupun memberikan pendekatan mekanistik tertentu dalam menentukan kapan kerugian sepanjang umur harus diakui. PSAK 71 juga tidak menentukan faktor-faktor yang harus dipertimbangkan oleh entitas dalam menyusun skenario masa depan pada saat mengestimasi KKE. Oleh karena itu, beberapa asumsi yang sebelumnya digunakan entitas pada saat pertama kali menerapkan model KKE (sebelum pandemi Covid19), atau yang telah diterapkan sebelumnya dalam hal entitas melakukan penerapan dini PSAK 71, mungkin tidak lagi relevan untuk kondisi saat ini (pada masa pandemi Covid-19). Entitas perlu meninjau kembali metodologi atau model KKE yang digunakan, dan mempertimbangkan informasi wajar dan terdukung yang tersedia pada tanggal pelaporan dalam mengukur KKE. Sebagai contoh, kebijakan pemberian jeda pembayaran baik atas pokok maupun bunga kepada suatu cluster debitur atau instrumen keuangan, misalnya karena pertimbangan tertentu atau mengikuti arahan kebijakan otoritas, tidak secara otomatis menghasilkan anggapan bahwa seluruh instrumen keuangan tersebut mengalami peningkatan risiko kredit yang signifikan.

Dalam menilai kondisi masa depan, entitas mempertimbangkan berbagai informasi relevan yang tersedia, termasuk misalnya dampak Covid-19 dan kebijakan yang dikeluarkan otoritas/pemerintah untuk mendukung dan memitigasi dampak penyebaran Covid-19 pada perekonomian. Dalam kondisi normal, penjadwalan ulang atau restrukturisasi piutang yang dilakukan oleh pemberi pinjaman (misalnya, bank dan lembaga keuangan lainnya) mengindikasikan adanya PSRK dan diikuti dengan pembentukan penyisihan KKE sepanjang umur. Debitur yang bisnisnya terkena dampak signifikan dari pandemi Covid-19 mungkin saja akan berhasil pulih dalam masa krisis pandemi Covid-19 berkat kebijakan-kebijakan relaksasi otoritas/pemerintah. Sebaliknya mungkin saja debitur yang bahkan sudah menerima fasilitas jeda pembayaran atau restrukturisasi dari pandemi Covid-19 tetap saja tidak dapat bertahan dan mengalami gagal bayar setelah pandemi Covid-19 berakhir. Entitas perlu melakukan identifikasi dan penilaian, dan menggunakan pertimbangan dalam menilai apakah debitur yang terdampak Covid-19 dapat kembali pulih dan memenuhi kewajiban kontraktualnya setelah berakhirnya jangka waktu restrukturisasi, sehingga tidak terjadi PSRK selama sisa umur ekspektasian dari piutang.

Entitas diingatkan bahwa pengukuran KKE berdasarkan PSAK 71 mengharuskan entitas untuk memperhitungkan dampak nilai waktu dari uang [PSAK 71 paragraf. 5.5.17 (b)]. Misalnya, peningkatan KKE tetap akan terjadi bahkan ketika entitas mengharapkan adanya pembayaran penuh atas pinjaman, namun terjadi penundaan pembayaran pinjaman dan bunga tidak diperhitungkan selama masa penangguhan pembayaran. Hal tersebut terjadi karena adanya kerugian dalam nilai kini dari arus kas. (iaiglobal.or.id)

\section{Teori Regulasi}

Formula pasar persaingan sempurna merujuk pada pasar efisien yakni tercipta interaksi yang aktif antara pemangku kepentingan. Kondisi tersebut diharapkan oleh neoleb dan kapitalis, namun tidak selamanya ekonomi akan stabil sehingga pasar tidak selamanya berada pada kondisi persainagan sempurna, jikalau tidak ada regulasi, tujuan sosial tidak bisa tercapai. (Wolk et al, 2017)

Meskipun demikian asumsi pasar efisen terbukti berperan penting dalam pengaturan standar. Alasan konseptual dan praktis asumsi efisiensi pasar secara khusus ketika merancang GAAP dengan asumsi inefisiensi pasar, maka tidak jelas akan mengarah pada keadaan keseimbangan efisiensi pasar. (Kothari et al, 2010)

Standar teori regulasi 'kepentingan publik' didasarkan pada dua asumsi. Pertama, pasar sering gagal karena masalah monopoli atau eksternalitas. Kedua, pemerintah dianggap mampu 
memperbaikinya kegagalan pasar melalui regulasi. Namun tidak jarang kepentingan publik menjadi landasan regulasi bagi ekonomi publik modern. (Shleifer. A, 2005)

Karakteristik krisis ekonomi dapat berupa krisis likuiditas, krisis keuangan dan munculnya model kapitalisme baru. Pemerintah harus memikirkan kebijakan investasi, kebijakan

\section{KESIMPULAN DAN SARAN}

Uraian ditas memberikan kesimpulan bahwa:

1) Pandemi Corona Virus Disease 2019 (Covid19) merupakan situasi yang belum pernah terjadi sebelumnya di mana pandemi kesehatan global telah berubah menjadi krisis ekonomi dan keuangan.

2) Dewan Standar Ikatan Akuntan IndonesiaIkatan Akuntan Indonesia (DSAK-IAI) dan Dewan Standar Syariah Ikatan Akuntan Indonesia (DSAS-IAI) telah berperan aktif melakukan evaluasi atas praktik akuntansi

3) Presiden Joko Widodo menunjukkan kepiawaiannya mempimpin bangsa dengan mengambil langkah strategis melalui pendaktan stategis usaha yang berpihak kepada pelaku usaha.

4) Langkah inovasi OJK sebagai regulator menerbitkan ketentuan penyesuaian

\section{DAFTAR PUSTAKA}

Laux, C. and C. L. (2010). Did Fair-Value Accounting Contribute to the Financial Crisis? Journal of Economic Perspectives, 24(1), 93-118.

Wolk, Harry I., James L. Dodd, dan J. J. R. (n.d.). No pendanaan, dan kebijakan kredit komersial. Jika pemerintah gagal menciptakan regulasinya krisis perbankan akan berubah menjadi krisis hutang negara. Investor akan mengubah objek kegiatan dengan menjual aset untuk menutupi kredit bank, berbagai kontak kembali dinegosiasikan ulang, mengurangi biaya operasional, karena tujuannya hanyalah: bertahan hidup dalam kondisi krisis.

penerapan Pernyataan Standar Akuntansi Keuangan (PSAK) 71 mengenai penghitungan pencadangan dan PSAK 68 mengenai pengukuran nilai wajar surat berharga merupakan antisipasi dan keberpihakan negara terhadap pemulihan ekonomi Indonesia.

5) Saat pandemi Covid-19, Teori akuntansi menunjukkan eksistensinya sebagai ilmu yang tidak sekedar mendiskusikan angka-angka laba-rugi, atau sekedar memposting debetkredit, angka-angka yang rigid tanpa nyawa, namun terbukti teori akuntansi telah menunjukkan pengaruhnya terhadap kehidupan sosial ekonomi yang menjadi kebutuhan utama manusia di zaman ini.

TitleAccounting Theory: Conceptual Issues in a Political and Economic Environment. SAGE. 